\title{
Learning Style Differences between Undergraduates, MBAs, Nonmanagement Workers, and Managers in Japan
}

\author{
Yoshitaka Yamazaki $^{1} \&$ Hitoshi Umemura ${ }^{1}$ \\ ${ }^{1}$ Faculty of Business Administration, Bunkyo University, Chigasaki, Japan \\ Correspondence: Yoshitaka Yamazaki, Faculty of Business Administration, Bunkyo University, 1100 Namegaya, \\ Chigasaki, Kanagawa, 253-8550 Japan. Tel: 81-467-53-2111.
}

Received: January 6, 2017

Accepted: January 17, 2017

Online Published: January 18, 2017

doi:10.5430/jbar.v6n1p1

URL: https://doi.org/10.5430/jbar.v6n1p1

\begin{abstract}
Using Kolb's experiential learning theory, this study aimed to explore how learning style differed among four cohorts: undergraduate management majors, master's of business administration (MBA) students, nonmanagement workers, and managers. The research context was Japan, with 1080 participants from two universities, one business school, and two different firms focused on sales and production. To compare the four cohors, this study applied a cross-sectional study. Results indicated that managers showed the strongest preference for active over reflective learning, followed by MBA students, nonmanagement workers, and undergraduates. Managers' active learning orientation did not statistically differ from that of MBA students, but did statistically differ from the groups of nonmanagement employees and undergraduates. With regard to the learning dimension of thinking versus feeling, MBA students were the most abstract learners, while the other three groups exhibited concrete learning orientations. The present research was the first to empirically compare groups according to career transitions from undergraduates towards management positions. This study provides insight on how individuals differ in learning styles as their careers develop.
\end{abstract}

Keywords: Career transitions, Salient roles, Learning style, Management development, Higher education, Japan

\section{Introduction}

\subsection{Career Development and Learning Style}

Several variables related to individual differences have been examined in relation to career development. A large segment of career research has addressed core self-evaluations (Ballout, 2009; Fort, Jacquet, \& Leroy, 2011), cognitive styles and abilities (Grimm \& Nachmias, 1977; Volodina, Nagy, \& Koller, 2015), and, above all, personality traits (Judge \& Kammeyer-Mueller, 2007; Seibert, Crant, \& Kraimer, 1999; Zacher, 2014). Although learning style is also an important differentiating variable (DuBrin, 2007), a very limited number of studies of learning style have been conducted related to career decision (Austin, 2004) and career planning (Moore, 1980). As a consequence, our understanding of how learning style relates to various aspects of career development remains inadequate.

Learning is an element of career development, particularly when individuals change roles in the workplace. Hall and Mirvis (1995) discussed how individuals' continuous learning affects their career adaptability and development. Those views suggest that individuals' learning leads them to acquire knowledge and skills to deal with new roles. Furthermore, if a new role is salient and different from a previous one, learning is believed to involve not only the acquisition of new knowledge and skills specific for the new role but also development of an adequate way of learning for the new role. Studying transition from the perspective of role identity, $\mathrm{Ng}$ and Feldman (2007) pointed out that students are expected to learn in a relatively passive fashion to gain knowledge in a class, while workers are expected to learn in a proactive manner in organizational contexts. If organizational workers were continuously passive learners like students, they might have more difficulty adjusting to their work roles.

Careers are thought to consist of a sequence of transitions between organizational roles (Trice \& Morand, 1989). Individuals must adjust to and engage with each work role transition (Ashforth \& Saks, 1995). The stage models (see Levinson, 1978; Schein, 1978; Super, 1957) describes a series of career events beginning with an individual's early work and lasting through retirement (Greenhaus \& Callanan, 2006). Because job roles during a career entail shaping 
a certain learning style in learning situations (Kolb, 1984), role shifts in transitions may require individuals to have certain learning styles. How individuals are inclined to particular learning styles appropriate to new roles caused by transitions is considered a critical issue, in that learning style relates to individuals' effectiveness in working situations (MacArthur, 1991). Since the career development literature does not address how learning style relates to salient work role, the present study aimed to fill this gap, specifically highlighting four career-stage cohorts: undergraduates, master's of business administration (MBA) students, nonmanagement workers, and managers.

\subsection{Salient Roles in Career Transition and Stages}

Individuals hold multiple positions in social networks and perform various roles in connection with the positions (Stets \& Harrod, 2004). Although individuals usually possess diverse role identities, research has indicated that they prioritize the role identities in a salience hierarchy according to the personal importance of each (Callero, 1985; Thoits, 1992). In accordance with the views of Super and Nevill (1986), Ng and Feldman (2007) documented that a role becomes salient compared to others based on three conditions: (1) the time spent in the role, (2) the psychological attachment to the role, and (3) the display of subjective values within the role. Based on this notion, the four roles examined in this study were thought to be salient or central in careers.

With regard to undergraduate student roles, $\mathrm{Ng}$ and Feldman (2007) indicated that the roles are salient in comparison with worker roles in organizations, and these two roles become mutually exclusive. As discussed earlier, students are expected to learn passively, whereas workers are more proactive learners. As a result, the first challenging transition occurs from school to work (Ng \& Feldman, 2007; Perrone \& Vickers, 2003), including the transition faced by those who complete their undergraduate degree and begin to work for organizations (Polach, 2004). Such individuals can experience a reality shock as they face unexpected organizational life and work (Okubo, 2006). For survival and adaptation, they need to learn how to react to work realities that include irrational or political elements (Schein, 1990).

It can be assumed that most workers have a nonmanagerial position, whose role, like that of undergraduate students, can be regarded as salient. Levinson's (1978) model showed that this phase of work is applied to the stage of early adulthood (ages 22 to 45 years), which includes a focus on not only pursuing and achieving career goals but also nonwork issues such as marriage and lifestyle and preparation for the next transition (Sullivan \& Crocitto, 2007). Schein's (1978) model of career anchors, which is complex but well cited in the literature (Sullivan \& Crocitto, 2007), has five stages from entry into the work role situation (Stage 2) to a period of mid-career crisis (Stage 6). Those stages require individuals to learn how to obtain full membership in the organization, subsequently organizing long-term career goals and managing the mid-career transition and crisis (Sullivan \& Crocitto, 2007).

According to Schein's (1978) model, Stage 6 has two career paths: becoming either a leader or a nonleader. A new manager or leader would experience work role transition within the organization and face challenges because the skills and knowledge required for management positions bear no resemblance to those for nonmanagement positions (Hill, 2007). As a result, new managers must strive to learn from experience (McCall, Lombardo, \& Morrison, 1988). When individuals become general managers as management specialists by way of experiencing junior and middle-level management positions, it is believed, particularly in North America, that they can run and manage various types of businesses (Trompenaars \& Hampden-Turner, 2004). All of these views suggest that management roles are salient and distinct from nonmanagement roles within the organization, requiring managers to learn leadership and management competencies by applying effective learning strategies.

There is another career path towards management positions in the boundaryless age: that of an MBA degree (Kelan \& Jones, 2009). Over the past several decades, studying for an MBA degree has become an increasingly popular way of career development through learning about management and leadership in business schools, yielding individual career opportunities (Sturges, Simpson, \& Altman, 2003). Completion of an MBA program typically requires 1 to 2 years of full-time study or several years of part-time study. Although MBA students spend a limited period in business school, they have the unique experience of work role transitions, going back to school from organizational work settings. Indeed, Kelan and Jones (2009) reported that MBA students developed a sense of community with their peers, holding unique identities and reflecting on the MBA value for forthcoming careers. Accordingly, the role of MBA students can be regarded as salient. As they seek to become managers in the future, MBA students actively learn in a class setting but are not like organizational workers or new managers who tend to learn from actual management experiences.

In summary, this study was intended to contribute to the literature on career development, focusing on the relatively broad career-stage cohort differences in learning style between undergraduates, nonmanagement workers, MBA students, and managers based on their salient work roles across career transitions. To address the research question of 
how learning style differs among those four cohorts, the study applied a learning model that encompasses learning styles. Finally, this study is composed of the present introduction followed by the explanation of learning style, methods, results, and discussion.

\section{Learning Style and Experiential Learning Theories}

The term "learning style" reflects a perspective that individuals differ in their preferred approaches to learning (Price, 2004). Although individuals have different styles of learning, groups with similar norms and common behaviors required from the environment tend to hold similar learning styles (Kolb, 1984) or common learning style traits (Hawk \& Shah, 2007). Learning styles have been theorized in several different ways (Peterson, Stephen, \& Armstrong, 2009; Richardson, 2011). Although variations exist in the learning style definitions and models, the intentions and approaches of researchers seem similar (Demirbas \& Demirkan, 2007). Among learning style models, this study chose Kolb's (1984) experiential learning theory. His learning theory, built upon intellectual methods for the processing of information (Cassidy, 2004), has been highly influential (Duff, 2004). More importantly, experiential-based learning theory is characterized as possessing developmental outcomes that focus on people's growth and change (Kayes, 2007). Accordingly, it seemed appropriate to apply Kolb's learning model for this study.

Building on the work of prominent scholars, including Dewey, Lewin, Piaget, James, Jung, and Freire (Kolb \& Kolb, 2005), Kolb (1984) developed a holistic model of individuals' learning processes. In his learning model, experience plays an important role as the basis for four learning modes: concrete experience (CE, feeling), reflective observation (RO, reflecting), abstract conceptualization (AC, thinking), and active experimentation (AE, acting).

To learn effectively, people must use all four learning modes (Kolb, 1984). The CE (feeling) mode involves feelings, sensing, and using intuition and sensitivities. In contrast, the AC (thinking) mode requires applying logical reasoning and conceptual analysis. The CE mode is dialectically opposed to the AC mode, so that the strength in one mode is a weakness in the other. The RO (reflecting) mode calls for perceiving the meaning of experiences and situations by carefully observing, listening, and reflecting. In contrast, the AE (acting) mode requires doing. The emphasis of the AE mode is to actively connect the external environment and world. Similar to the relationship between the CE and AC modes, the RO (reflecting) mode is dialectically opposed to the AE (acting) mode, so that there is a conflicting relationship between them. Thus, in Kolb's (1984) theory, two kinds of learning dimensions are present: the AC vs. $\mathrm{CE}$ dimension and the $\mathrm{AE}$ vs. RO dimension, both of which describe a bipolar continuum.

A combination of two learning modes from each of the two dialectical learning dimensions generates the four fundamental learning styles (Kolb, 1984; Kolb \& Kolb, 2005). The diverging learning style specializes in the two modes of CE (feeling) and RO (reflecting). Conversely, the converging learning style specializes in the AC (thinking) and $\mathrm{AE}$ (acting) modes. The assimilating learning style emphasizes the two modes of AC (thinking) and RO (reflecting). In contrast, the accommodating learning style emphasizes the CE (feeling) and AE (acting) modes. Figure 1 presents Kolb's learning model.

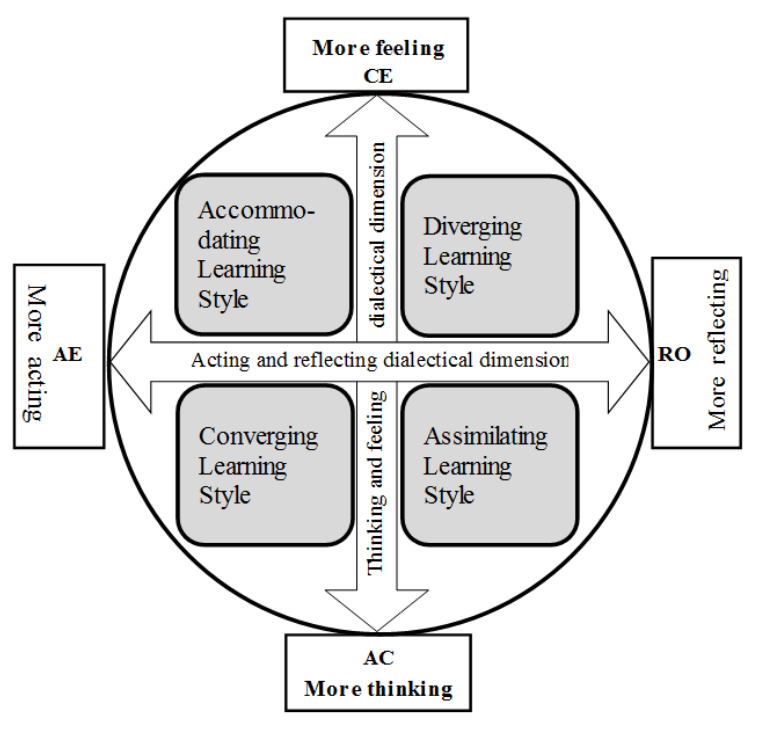

Figure 1. Kolb’s Learning Model 


\section{Methods}

\subsection{Research Sites}

This study selected Japan as a research context. Individuals' career development has become more important in Asia, particularly Japan, where employment systems have been changing dramatically. Although Japanese organizations still use lump-sum hiring of new undergraduates based on long-term employment practices (Kaino, Ouchi, Owan, \& Hirano, 2011), they have begun to adopt a performance-based employment system, especially at the management level (Nannichi \& Ohira, 2014). As the seniority system is replaced, a performance-based employment system may also be implemented for nonmanagerial employees in the future and would then affect how they work in their lifelong career. In the changing employment system, both individuals and organizations need to more actively manage individuals' career development in a way that reflects their career wishes. It is believed that results of this study could be beneficial for career development seekers, human resources professionals, as well as career counselors in higher education and professional institutions when employment systems change.

\subsection{Research Procedures and Participants}

To examine the learning style of undergraduates, MBA students, nonmanagement workers, and managers, this study selected two universities for undergraduates, one business school, and two firms with two different lines of business: sales and production. The two types of career choices were used since Holland's (1992) theory indicates that personality factors relate to individuals' vocational choice.

At the two universities, University A and University B, the study focused on students majoring in business administration or management, most of whom will likely work for corporations after graduation. University A is located near Tokyo, while University B is near Chubu, between Tokyo and Osaka. Potential subjects were recruited from classes. At University A, 223 questionnaires were distributed, and 206 completed questionnaires were usable. Similarly, at University B, 400 survey packets were distributed, and 336 completed questionnaires were usable. MBA students at a business school, all of whom were full-time students, were also invited to participate in this research. Because of a detailed explanation of the questionnaires during classes, all of the questionnaires that were collected were valid, yielding 102 usable questionnaires for this study.

Two Japanese firms participated in this research. Firm A manufactures electronic communication goods in a rural area of Japan, while Firm B markets and sells office machines to organizations in a metropolitan area. Both firms are well known and successful multinational organizations in Japan. After receiving permission from these firms, survey packets were distributed to employees through the human resources department of each firm. At Firm A, of the 330 surveys sent, 229 completed surveys were usable, providing data from individuals working on production lines. Firm B received 420 surveys, and 258 questionnaires were completed and usable in order to analyze data involving sales-focused employees. Table 1 describes the demographic characteristics of all participants.

Table 1. Demographic Characteristics of Japanese Participants

\begin{tabular}{|c|c|c|c|c|c|c|c|}
\hline & \multicolumn{3}{|c|}{ Undergraduate students } & \multirow{2}{*}{$\begin{array}{c}\text { MBA students } \\
\text { Business } \\
\text { school }\end{array}$} & \multicolumn{3}{|c|}{ Organizational employees } \\
\hline & Total & University A & University B & & Total & $\begin{array}{c}\text { Firm A } \\
\text { (Production) }\end{array}$ & $\begin{array}{l}\text { Firm B } \\
\text { (Sales) }\end{array}$ \\
\hline$N$ & 542 & 206 & 336 & 102 & 487 & 229 & 258 \\
\hline \multicolumn{8}{|l|}{ Age } \\
\hline Mean & 19.8 & 19.3 & 20.2 & 32.1 & 36.9 & 39.8 & 34.5 \\
\hline $\mathrm{SD}$ & 2.0 & 1.5 & 2.1 & 4.5 & 8.6 & 7.5 & 8.7 \\
\hline \multicolumn{8}{|l|}{ Gender } \\
\hline Male & 443 & 158 & 285 & 90 & 379 & 173 & 206 \\
\hline Female & 99 & 48 & 51 & 12 & 108 & 56 & 52 \\
\hline \multicolumn{8}{|l|}{ Grade year } \\
\hline Freshman & 182 & 102 & 80 & & & & \\
\hline Sophomore & 137 & 58 & 79 & & & & \\
\hline Junior & 151 & 30 & 121 & & & & \\
\hline Senior & 72 & 16 & 56 & & & & \\
\hline \multicolumn{8}{|l|}{ Positions } \\
\hline Nonmanagement & & & & & 366 & 173 & 193 \\
\hline Management & & & & & 121 & 56 & 65 \\
\hline \multicolumn{8}{|l|}{ Tenure } \\
\hline Mean & & & & & 15.9 & 20.7 & 11.6 \\
\hline $\mathrm{SD}$ & & & & & 9.2 & 8.1 & 8.0 \\
\hline
\end{tabular}




\subsection{Measures}

To investigate participants' learning styles, this study applied Kolb's (1999) Learning Style Inventory (LSI) that was developed based on experiential learning theory (Kolb, 1984). The LSI is designed to reflect the dialectical nature of concrete experience $(\mathrm{CE}=$ feeling $)$ vs. abstract conceptualization $(\mathrm{AC}=$ thinking $)$ and reflective observation $(\mathrm{RO}=$ reflecting) vs. active experimentation ( $\mathrm{AE}=$ acting). The third version of the LSI, with the revised psychometrics suggested by Veres, Sims, and Locklear (1991), resulted in improved reliability (Veres et al., 1991; Kayes, 2005). This study used a Japanese translation of this LSI version that had been applied in past investigations for Japanese learning styles (see Yamazaki \& Kayes, 2007).

The LSI has 12 questions, each of which requires prioritizing four statements-from 4, you learn most, to 1, you learn least - as a forced-choice method based on individual preference for learning. The four statements correspond to the four learning modes: CE (feeling), AC (thinking), RO (reflecting), and AE (acting), describing "I trust my hunches and feelings," "I rely on logical thinking," "I listen and watch carefully," and "I work hard to get things done," respectively. The total score for one learning mode shows the extent to which an individual prefers to use that mode in his or her learning process. Furthermore, the value gained by subtracting the total score of one learning mode from that of the other in the same learning dimension - the value of $\mathrm{AC}-\mathrm{CE}$ or $\mathrm{AE}-\mathrm{RO}$ - represents how an individual prefers to learn by using one learning mode over the other in each of the dialectical dimensions. The value describes a relative preference for individual learning, which becomes a basis to determine four learning styles.

A value of $\mathrm{AC}-\mathrm{CE}$ that approaches 36 represents a specialization in $\mathrm{AC}$, whereas a value approaching -36 represents a specialization in CE. Similarly, a value of $\mathrm{AE}-\mathrm{RO}$ that approaches 36 represents a specialization in $\mathrm{AE}$ (acting), whereas a value approaching -36 indicates a specialization in RO. According to normative scores proposed by Kolb (1999) for the third version of the LSI, the cut-off point for the value of AC - CE is 4.30, whereas the cut-off point for the value of $\mathrm{AE}-\mathrm{RO}$ is 5.9. The combination of these two values determines the choice of one of four learning styles.

\section{Results}

Before examining how learning style varies with four different cohorts-undergraduates, MBA students, nonmanagement workers, and managers - the present study checked whether participants of the two universities possessed the same learning modes and styles, as well as participants of the two different firms. Results of the independent t-test showed no significant differences between University A students and University B students regarding the six learning style variables of $\mathrm{CE}$ (feeling), AC (thinking), RO (reflecting), AE (acting), AC - CE (relative preference for AC vs. CE), and AE - RO (relative preference for AE vs. RO) (all six variables, $\mathrm{p}>0.05$ ). Furthermore, results of the analysis of variance also showed no significant difference in these six learning style variables between freshmen, sophomores, juniors, and seniors (all six variables, $p>0.05$ ). Thus, the undergraduate students of those two universities were assumed to be the same cohort of a career-stage group for this study. With regard to the two firms, there were significant differences in the CE and RO modes $(\mathrm{p}<0.05)$, but no significant differences for the other four learning variables ( $\mathrm{AC}, \mathrm{AE}, \mathrm{AC}-\mathrm{CE}$, and $\mathrm{AE}-\mathrm{RO}$ variables, $\mathrm{p}>0.05$ ). Thus, the participants of Firm A with a production career focus were distinct from those of Firm B with a sales career orientation, so this study analyzed learning style differences between the cohorts in three iterations: (1) considering all employees of Firms A and B; (2) considering production career-focused employees from Firm A; and (3) considering sales career-focused employees from Firm B.

\subsection{Six Learning Style Variables}

\subsubsection{Analyses Involving All Employees of Firms A and B}

This study applied analysis of variance (ANOVA) to examine differences in six learning style variables between the four cohorts. First, concerning employees of both firms, results of ANOVA showed that the four cohorts differed significantly in all six learning style variables: $\mathrm{CE}$ (feeling, $\mathrm{F}=17.50, \mathrm{p}<0.01$ ), AC (thinking, $\mathrm{F}=22.98, \mathrm{p}<0.01$ ), $\mathrm{RO}$ (reflecting, $\mathrm{F}=10.73, \mathrm{p}<0.01), \mathrm{AE}$ (acting, $\mathrm{F}=6.36, \mathrm{p}<0.01), \mathrm{AC}-\mathrm{CE}(\mathrm{F}=24.47, \mathrm{p}<0.01)$, and $\mathrm{AE}-\mathrm{RO}(\mathrm{F}$ $=8.58, \mathrm{p}<0.01)$. Undergraduates used CE modes most, followed in turn by managers, nonmanagement workers, and MBA students. Results of the Bonferroni test showed a significant difference between undergraduates and MBA students (mean difference [M.D.] $=5.12, \mathrm{p}<0.01$ ), between undergraduates and nonmanagement employees (M.D. $=1.66, \mathrm{p}<0.01$ ), between MBA students and nonmanagement employees (M.D. $=-3.46, \mathrm{p}<0.01$ ), and between MBA students and managers (M.D. $=-3.72, \mathrm{p}<0.01$ ). In contrast, MBA students applied the AC mode the most, followed by managers, nonmanagement workers, and undergraduates. Results of the Bonferroni test showed significant differences between MBA students and each of the three cohorts: undergraduates (M.D. $=-7.52, p<0.01$ ), 
nonmanagement employees (M.D. $=7.41, \mathrm{p}<0.01$ ), and managers (M.D. $=7.29, \mathrm{p}<0.01$ ); however, there was no statistically significant difference among those three cohorts.

Undergraduates and nonmanagement workers showed similar values for RO (reflecting, 30.71 and 30.85 for undergraduates and nonmanagement, respectively), as did MBA students and nonmanagers (27.27 and 28.77, respectively). Based on the Bonferroni test, the former two cohorts (undergraduates and nonmanagement) differed significantly from the latter two cohorts (MBA students and managers): that is, there was a difference between undergraduates and MBA students (M.D. $=3.43, \mathrm{p}<0.01$ ), between undergraduates and managers (M.D. $=1.94, \mathrm{p}<$ 0.05 ), between MBA students and nonmanagement (M.D. $=-3.57, \mathrm{p}<0.01$ ), and between nonmanagement and managers (M.D. $=2.08, \mathrm{p}<0.05$ ). For the AE (acting) mode, there was only a significant difference between undergraduates and managers (M.D. $=-3.11, \mathrm{p}<0.05$ ).

The variables of $\mathrm{AC}-\mathrm{CE}$ and $\mathrm{AE}-\mathrm{RO}$ indicate a relative preference for one learning mode over the other. There was a statistically significant difference in the value of $\mathrm{AC}-\mathrm{CE}$ between MBA students and each of the other three cohorts - undergraduates (M.D. $=-12.64, \mathrm{p}<0.01$ ), nonmanagement (M.D. $=10.90, \mathrm{p}<0.01$ ), and managers (M.D. $=11.01, \mathrm{p}<0.01)$. The MBA students strongly preferred to learn by using the AC rather than CE mode, but the other three cohorts preferred the CE mode. Finally, results of the Bonferroni test of AE - RO showed significant differences between undergraduates and MBA students (M.D. $=-4.47, \mathrm{p}<0.01$ ), between undergraduates and managers (M.D. $=-5.05, \mathrm{p}<0.01$ ), and between nonmanagement workers and managers (M.D. $=-3.75, \mathrm{p}<0.05$ ). Managers were the most active and least reflective learners, followed by MBA students, nonmanagement workers, and undergraduates.

Table 2 summarizes results of the ANOVA with the Bonferroni tests. In addition, Figure 2a depicts learning style differences between the four career-stage cohorts, indicating the different learning styles over the career stages, and Figure 3a shows different degrees of four learning modes between these four cohorts.

Table 2. Results of the Analysis of Variance and Bonferroni Tests of Learning Style Variables

\begin{tabular}{|c|c|c|c|c|c|c|c|c|c|c|c|c|c|c|}
\hline & & \multirow{2}{*}{$N$} & \multicolumn{2}{|c|}{$\mathrm{CE}$ (fealing) } & \multicolumn{2}{|c|}{$\mathrm{AC}$ (thinking) } & \multicolumn{2}{|c|}{$\mathrm{RQ}$ (reflecting) } & \multicolumn{2}{|c|}{$\mathrm{AE}$ (acting) } & \multicolumn{2}{|c|}{$\mathrm{ACCE}$} & \multicolumn{2}{|c|}{$A E=R Q$} \\
\hline & & & Mean & $\mathrm{SD}$ & Mean & SD & Mean & SD & Mean & SD & Mean & SD & Mean & SD \\
\hline \multicolumn{2}{|c|}{ Undergraduates (Common) } & 542 & 31.32 & 6.58 & 26.60 & 8.79 & 30.71 & 6.26 & 31.37 & 7.26 & -4.73 & 13.69 & 0.66 & 11.42 \\
\hline \multicolumn{2}{|c|}{ MBA students (Common) } & 102 & 26.21 & 6.41 & 34.12 & 7.35 & 27.27 & 7.36 & 32.40 & 6.56 & 7.91 & 11.98 & 5.13 & 12.15 \\
\hline \multirow{10}{*}{$\begin{array}{c}\text { All } \\
\text { Employe es }\end{array}$} & Non-MGT workers & 366 & 29.66 & 7.04 & 26.71 & 8.90 & 30.85 & 6.58 & 32.62 & 7.99 & -2.99 & 13.98 & 1.96 & 11.81 \\
\hline & Managers & 121 & 29.93 & 729 & 26.83 & 8.27 & 28.77 & 7.62 & 34.48 & 7.71 & -3.10 & 14.03 & 5.71 & 13.74 \\
\hline & $F$ & & \multicolumn{2}{|c|}{$17.50 * *$} & \multicolumn{2}{|c|}{$22.98^{* *}$} & \multicolumn{2}{|c|}{$10.73^{* *}$} & \multicolumn{2}{|c|}{$6.36 * *$} & \multicolumn{2}{|c|}{$24.47 * *$} & \multicolumn{2}{|c|}{$8.58^{* *}$} \\
\hline & \multicolumn{2}{|c|}{ Bonferroni test } & $\mathrm{MD}$ & $\mathrm{SE}$ & MD & $\mathrm{SE}$ & $\mathrm{MD}$ & $\mathrm{SE}$ & $\mathrm{MD}$ & $\mathrm{SE}$ & $\mathrm{MD}$ & $\mathrm{SE}$ & $\mathrm{MD}$ & SE \\
\hline & \multicolumn{2}{|c|}{ Undergraduates vs. MBA } & $5.12^{* *}$ & 0.73 & $-7.52 * *$ & 0.93 & $3.43 * *$ & 0.71 & -1.03 & 0.81 & $-12.64 * *$ & 1.48 & $-4.47 * *$ & 1.28 \\
\hline & \multicolumn{2}{|c|}{ Undergraduates vs. Non-MGT } & $1.66^{* *}$ & 0.46 & -0.12 & 0.59 & -0.14 & 0.45 & $-1.25^{+}$ & 0.51 & -1.74 & 0.93 & -1.30 & 0.80 \\
\hline & \multicolumn{2}{|c|}{ Undergraduates vs. MGT } & 1.40 & 0.68 & -0.23 & 0.87 & $1.94 *$ & 0.67 & $-3.11 *$ & 0.75 & -1.63 & 1.38 & $-5.05 * *$ & 1.19 \\
\hline & \multicolumn{2}{|c|}{ MBA vs. Non-MGT } & $-3.46 * *$ & 0.76 & $7.41^{* *}$ & 0.97 & $-3.57 * *$ & 0.74 & -0.22 & 0.84 & $10.90 * *$ & 1.53 & 3.17 & 1.33 \\
\hline & \multicolumn{2}{|c|}{ MBA vs. MGT } & $-3.72 * *$ & 0.91 & $7.29 * *$ & 1.16 & -1.49 & 0.89 & -2.08 & 1.01 & $11.01 * *$ & 1.84 & -0.58 & 1.60 \\
\hline & \multicolumn{2}{|c|}{ Non-MGT vs. MGT } & -0.26 & 0.71 & -0.11 & 0.91 & $2.08^{*}$ & 0.69 & -1.86 & 0.79 & 0.11 & 1.43 & $-3.75^{*}$ & 1.25 \\
\hline \multirow{11}{*}{$\begin{array}{l}\text { Production } \\
\text { Firm } \\
\text { Employees }\end{array}$} & & $N$ & Mean & SD & Mean & $S D$ & Mean & SD & Mean & SD & Mean & SD & Mean & SD \\
\hline & Non-MGT workers & 173 & 28.58 & 7.11 & 25.87 & 8.48 & 32.14 & 5.79 & 33.07 & 8.42 & -2.80 & 13.62 & 1.32 & 11.06 \\
\hline & Managers & 56 & 27.93 & 7.29 & 26.45 & 7.06 & 30.48 & 7.78 & 35.14 & 7.79 & -1.48 & 12.61 & 4.66 & 13.98 \\
\hline & $F$ & & & & & & & & & & 25 & & 5.6 & \\
\hline & Bonferron & & $\mathrm{MD}$ & $\mathrm{SE}$ & MD & $\mathrm{SE}$ & $\mathrm{MD}$ & $\mathrm{SE}$ & $\mathrm{MD}$ & $\mathrm{SE}$ & $\mathrm{MD}$ & $\mathrm{SE}$ & $\mathrm{MD}$ & SE \\
\hline & Undergraduates & & $5.11^{* *}$ & 0.73 & $-7.52^{* *}$ & 0.91 & $3.43 * *$ & 0.69 & -1.03 & 0.81 & $-12.64 * *$ & 1.45 & $-4.47^{* *}$ & 1.25 \\
\hline & Undergraduates & MGT & $2.74 * *$ & 0.59 & 0.72 & 0.74 & $-1.44^{\dagger}$ & 0.56 & $-1.70^{+}$ & 0.65 & -1.93 & 1.17 & -0.66 & 1.01 \\
\hline & Undergraduates & & $3.39 * *$ & 0.94 & 0.15 & 1.19 & 0.23 & 0.90 & $-3.77 *$ & 1.05 & -3.24 & 1.88 & $-4.00^{+}$ & 1.63 \\
\hline & MBA vs. Non- $N$ & & $-2.38 *$ & 0.84 & $8.25 * *$ & 1.06 & $-4.87 * *$ & 0.80 & -0.67 & 0.93 & $10.71 * *$ & 1.68 & $3.81^{+}$ & 1.45 \\
\hline & MBA vs. MGT & & -1.72 & 1.12 & $7.67^{* *}$ & 1.41 & $-3.21 *$ & 1.07 & -2.74 & 1.24 & $9.39 * *$ & 2.23 & 0.47 & 1.93 \\
\hline & Non-MGT vs. M & & 0.66 & 1.03 & -0.57 & 1.30 & 1.66 & 0.99 & -2.07 & 1.15 & -1.32 & 2.06 & -3.34 & 1.79 \\
\hline & & $N$ & Mean & $\mathrm{SD}$ & Mean & SD & Mean & SD & Mean & $S D$ & Mean & SD & Mean & SD \\
\hline & Non-MGT w otkers & 193 & 30.63 & 6.85 & 27.47 & 9.22 & 29.68 & 7.03 & 32.22 & 7.58 & -3.16 & 14.32 & 2.54 & 12.46 \\
\hline & Managers & 65 & 31.65 & 6.88 & 27.15 & 9.23 & 27.29 & 7.21 & 33.91 & 7.65 & -4.49 & 15.11 & 6.62 & 13.57 \\
\hline & $F$ & & & & & & & & & & 24 & & 8.0 & \\
\hline Sales & Bonferron & & $\mathrm{MD}$ & $\mathrm{SE}$ & MD & $\mathrm{SE}$ & $\mathrm{MD}$ & SE & $\mathrm{MD}$ & $\mathrm{SE}$ & $\mathrm{MD}$ & SE & $\mathrm{MD}$ & SE \\
\hline Firm & Undergraduates & & $5.12^{* *}$ & 0.72 & $-7.52 * *$ & 0.95 & $3.43 * *$ & 0.72 & -1.03 & 0.79 & $-12.64 * *$ & 1.48 & $-4.47 * *$ & 1.28 \\
\hline Employees & Undergraduates & MGT & 0.70 & 0.56 & -0.87 & 0.73 & 1.02 & 0.56 & -0.85 & 0.61 & -1.57 & 1.15 & -1.88 & 1.00 \\
\hline & Undergraduates & & -0.32 & 0.87 & -0.56 & 1.15 & $3.42 * *$ & 0.87 & $-2.54^{*}$ & 0.96 & -0.23 & 1.81 & $-5.95 * *$ & 1.56 \\
\hline & MBA vs. Non- $\mathrm{N}$ & & $-4.42 * *$ & 0.81 & $6.65^{* *}$ & 1.07 & $-2.41 *$ & 0.81 & 0.18 & 0.89 & $11.07 * *$ & 1.68 & 2.59 & 1.46 \\
\hline & MBA vs. MGT & & $-5.44 * *$ & 1.05 & $6.96^{* *}$ & 1.39 & -0.02 & 1.05 & -1.51 & 1.16 & $12.40^{* *}$ & 2.18 & -1.49 & 1.89 \\
\hline & Non-MGT vs.M & & -1.02 & 0.95 & 0.31 & 1.26 & $2.39^{+}$ & 0.95 & -1.68 & 1.04 & 1.33 & 1.97 & -4.08 & 1.71 \\
\hline
\end{tabular}

$\dagger \mathrm{p}<0.10, * \mathrm{p}<0.05, * * \mathrm{p}<0.01$.

Note on Table 2. Statistics for undergraduates and master's of business administration (MBA) students are used for 
all three comparative analyses: all employees, production firm employees, and sales firm employees. A greater value of $\mathrm{AC}-\mathrm{CE}$ indicates that the specialization in $\mathrm{AC}$ (thinking) is stronger than that in $\mathrm{CE}$ (feeling). A greater value of $\mathrm{AE}-\mathrm{RO}$ indicates that specialization in $\mathrm{AE}$ (acting) is stronger than that in $\mathrm{RO}$ (reflecting).

(a)

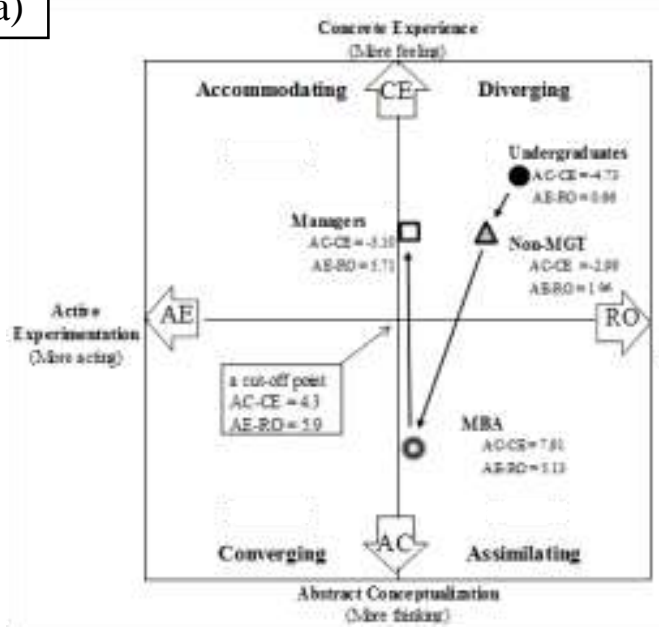

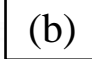

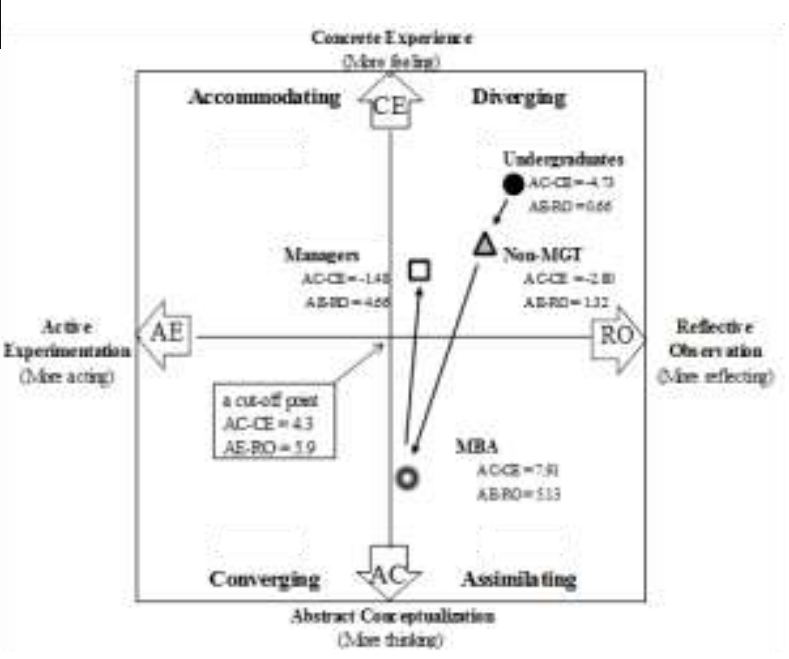

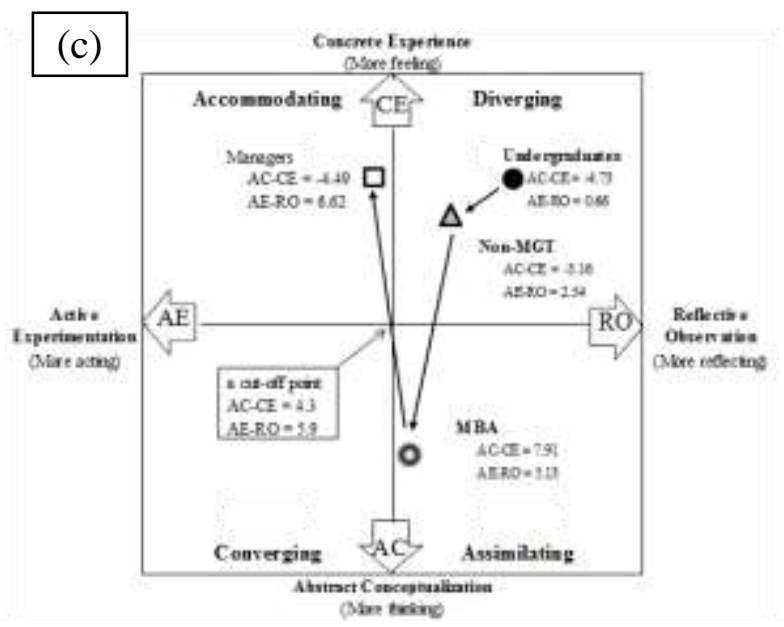

Figure 2. Learning style differences between undergraduates, MBA students, nonmanagement employees, and management employees - with employees from (a) both firms, (b) only a production firm, and (c) only a sales firm

\subsubsection{Analyses Involving Sales-Focused Employees (Firm B)}

The significant differences between groups for the six learning style variables continued when the comparison was only with employees from Firm B (Table 2). In this analysis, MBA students continued to have the lowest CE score and the highest AE score $(\mathrm{p}<0.01)$. The RO mode values ranged from a high of 30.71 for undergraduates to a low of 27.27 for MBA students, with significant differences between undergraduates and managers, between MBA students and nonmanagement employees, and between undergraduates and MBA students. For the AE mode, the only significant difference was between undergraduates and managers; managers applied AE modes the most.

As shown in Table 2, despite some differences in the statistical significance of various comparisons, MBA students had significantly higher AC - CE values than the other cohorts for all analyses, including that of the sales employees. The sales firm managers had the highest value of all the groups for AE - RO (6.62 compared with 5.13 for MBA students, 2.54 for nonmanagers, and 0.66 for undergraduates, as well as 4.66 for production managers and 1.32 for production nonmanagers). Figure $2 \mathrm{c}$ describes learning style differences between the four career-stage cohorts, whereas Figure $3 \mathrm{c}$ depicts different degrees of four learning modes between these four cohorts. 

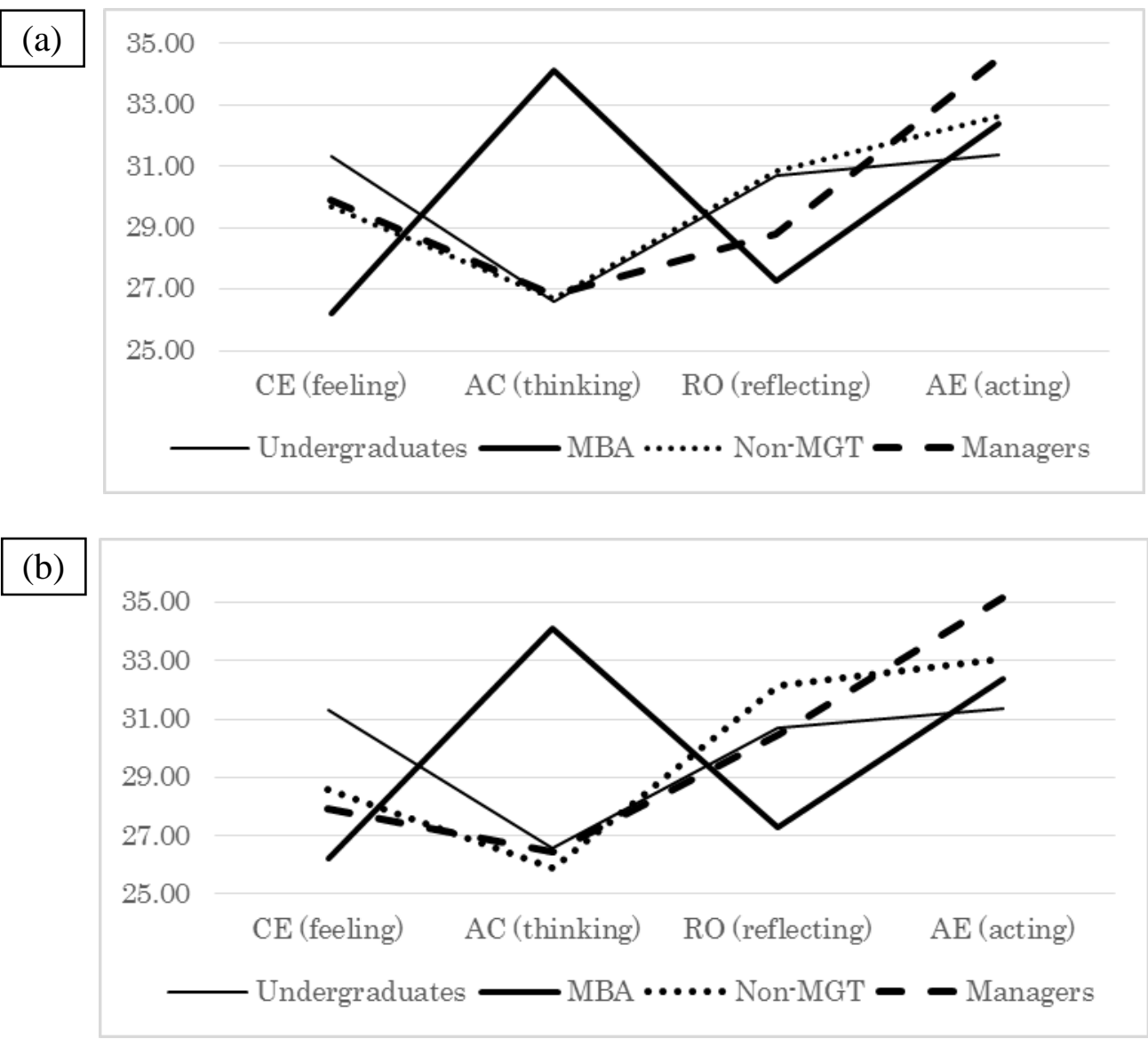

(c)

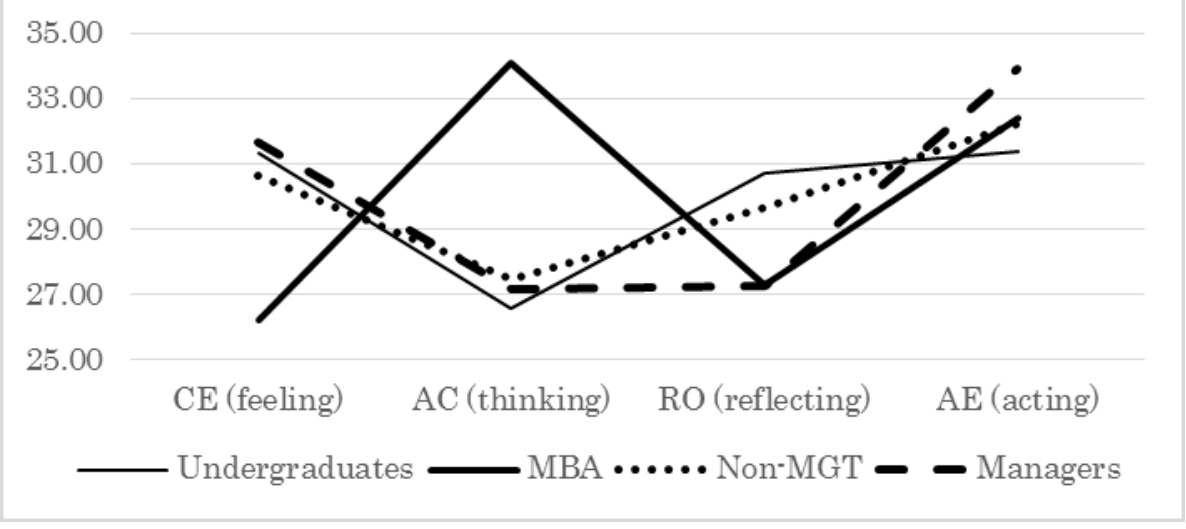

Figure 3. Learning mode differences between undergraduates, MBA students, nonmanagement employees, and management employees - with employees from (a) both firms, (b) only a production firm, and (c) only a sales firm

\subsection{Learning Styles Distribution}

\subsubsection{Analyses Involving All Employees of Firms A and B}

A chi-square test between four learning styles and the four cohorts showed a significant relationship between them $(\chi 2=115.14, p<0.01)$, suggesting that learning styles change with the cohorts (Table 3(A)). The biggest change of adjusted standard residuals was a difference in the diverging learning style, which specializes in CE (feeling) and RO (reflecting) modes $(5.57,-4.72,-1.61$, and -2.20 for undergraduates, MBA students, nonmanagement employees, and managers, respectively) as well as a difference in the converging learning style, which specializes in $\mathrm{AC}$ (thinking) and $\mathrm{AE}$ (acting) modes $(-4.37,8.62,-1.81$, and 1.81 in the same order). Additionally, it should be noted 
that the most dominant learning style varied with the four cohorts: for undergraduates, it was a diverging learning style (46\%); for MBA students, a converging style (30\%); and for nonmanagement workers and managers, an accommodating style ( $37 \%$ and $41 \%$, respectively).

Table 3. Results of the Chi-Square Test of Independence by Learning Styles and Four Cohorts

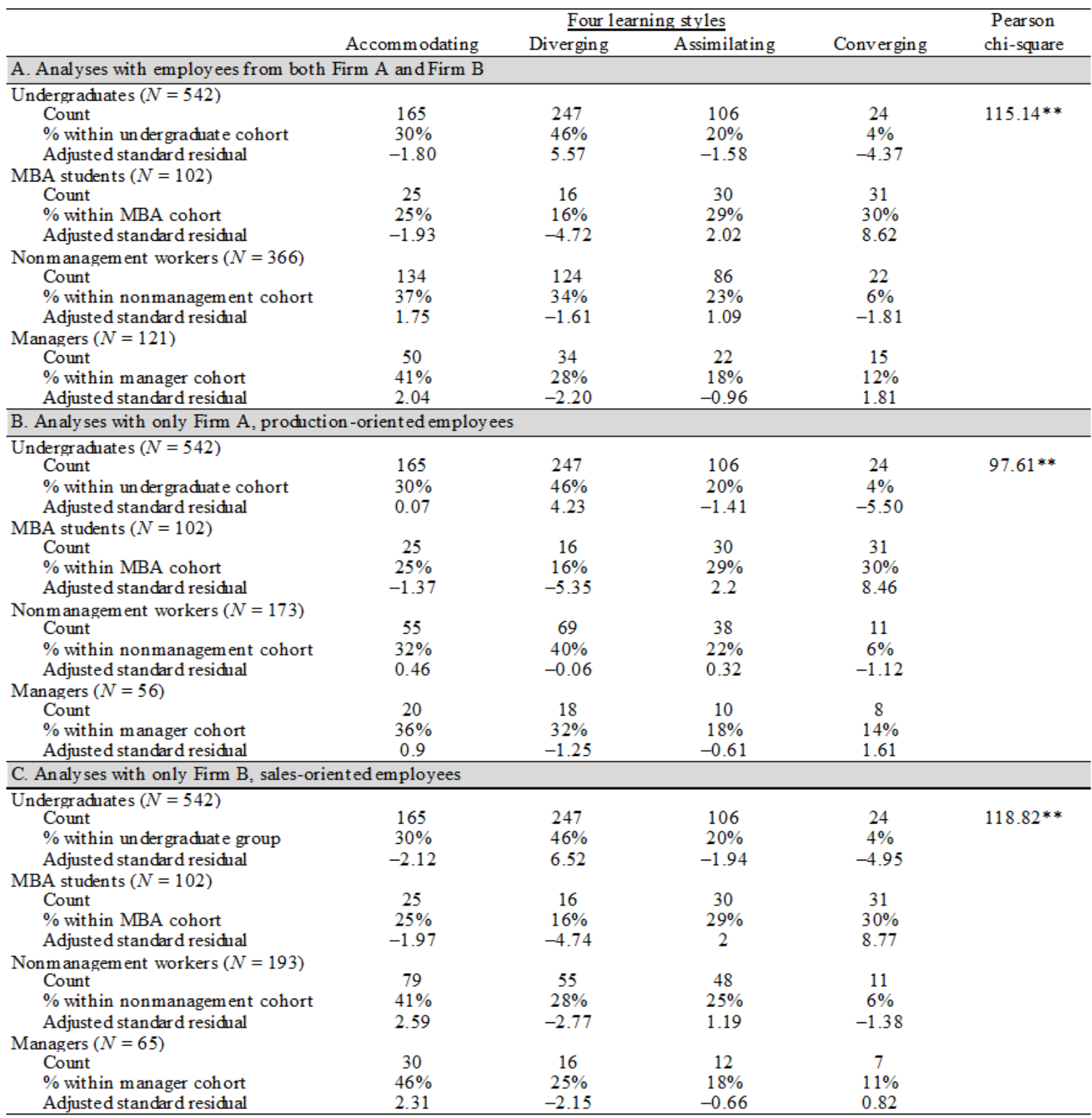

$* * \mathrm{p}<0.01$

\subsubsection{Analyses Involving Production-Focused Employees (Firm A)}

As depicted in Table 3(B), results of a chi-square test showed a significant relationship between the four learning styles and the four cohorts $(\chi 2=97.61, p<0.01)$. Similar to the results with all employees, the biggest change of adjusted standard residuals occurred in the diverging and converging learning styles. However, the most dominant learning style of nonmanagement workers in this production-oriented firm was a diverging learning style (40\%), while that of managers was an accommodating style (36\%).

\subsubsection{Analyses Involving Sales-Focused Employees (Firm B)}

Again, there was a significant association between the four learning styles and the four cohorts $(\chi 2=118.82, p<0.01)$ (Table $3(\mathrm{C})$ ). The pattern of the change of adjusted standard residuals with these sales-oriented employees resembled 
that of the production-oriented employees, with differences in the diverging and converging learning styles. As with the overall analysis, the most dominant learning style for nonmanagement workers and managers was an accommodating learning style ( $41 \%$ and $46 \%$, respectively), which suggests that learning style orientation from nonmanagement workers towards management positions may tend to vary with individuals' different career focus.

\section{Discussion}

\subsection{Relationships between Learning Style and Careers}

This study provides insight on how individuals differ in learning styles as their careers develop. Results showed that among the cohorts studied, managers had the strongest preference for active over reflective modes. Further, MBA students were the most abstract learners, while the other three cohorts exhibited a concrete learning orientation. Based on the research findings, this section discusses three main points, yielding two conclusions. It then offers theoretical and practical implications and addresses study limitations.

First, regarding the relationship between learning style and career stage, this study found that the four distinct career-stage cohorts possessed different learning modes and styles. For example, when comparing employees from both firms, undergraduate students used CE modes the most, followed by managers, nonmanagement workers, and MBA students. Results that considered only the production- or sales-focused employees had a slightly different order. In contrast, MBA students were more strongly oriented to an AC mode than the other three cohorts. As another example, the highest percentage of undergraduates had a diverging learning style, whereas MBA students had a converging style and managers and nonmanagement workers tended to have an accommodating learning style. A handful of learning style difference studies have documented distinction of learning styles and modes according to work differences. For example, Brown and Burke (1987) showed a difference in learning styles between accounting major undergraduates and professional accountants who had a few years of work experience, suggesting that the undergraduates typically had a diverging learning style, while the accountants had a converging learning style as a dominant one. Accordingly, the empirical evidence provided in this study along with that in past studies leads to the first conclusion: Individuals are likely to differ in learning styles according to their career stages that encompass salient work roles such as undergraduate, MBA student, nonmanagement worker, and manager.

The second element of discussion involves a unique feature of MBA student learning styles. MBA students in this study had a strong skewness towards the AC (thinking) mode and a relative orientation towards the AE (acting) mode. Thus, the most common learning style of MBA students was the converging style, which was the least represented in the other cohorts. When looking at other MBA learning styles, Boyatzis and Mainemelis (2000) reported that American full-time MBA students also lean toward a converging learning style, with a value of AC - CE of 7.48 and $\mathrm{AE}-\mathrm{RO}$ of 4.82. Those values are almost identical to those of the Japanese MBA students examined for this study (with values of $\mathrm{AC}-\mathrm{CE}=7.91$ and $\mathrm{AE}-\mathrm{RO}=5.13$ ). $\mathrm{MBA}$ educational environments may, in general, require applying strong $\mathrm{AC}$ modes with a relative shift to $\mathrm{AE}$ modes. However, the learning style of the converging orientation seems to be very unique among career stages and transitions of Japanese firm employees. Thus, the second conclusion is made: Learning styles of MBA students are heavily inclined toward an AC (thinking) mode and relatively directed to an AE (acting) mode, which is typical of MBA learning styles. Those who graduate from business school may struggle with adapting to organizational environments strongly requiring $\mathrm{CE}$ (feeling) modes. Work transition after business school may be a critical issue, particularly in Japan.

The third point for discussion concerns vocational choices to be considered when studying learning style differences with career development. Although the present study examined learning style differences in career stages from undergraduates towards management, it also found that learning styles varied with vocational differences between a production career focus and a sales career focus. Ng and Feldman (2007) argued that work role identity-the focus of this study - differs from vocational identity. Vocational identity involves self-perceptions against lasting skills, capabilities, and motives that individuals hold across jobs in their career (Holland, Gottfredson, \& Power, 1980) and considers an individual's vocational choice (Holland, 1992). According to the Holland hexagon model, production employees might belong to the Realistic category, while sales employees seem to belong to the Enterprising category. Because of learning style differences in vocational choices based on the study results, it is important to research how learning styles relate to other vocational choices, which may affect the relationship between career stages with a salient work role and learning styles.

\subsection{Implications}

The results of this study offer important theoretical and practical implications in the area of career development. Kolb (1984) argued that learning style is determined by the interaction between the person and the environment 
(Kolb \& Kolb, 2005), which can be considered as work roles in career development. Similarly, learning style remains malleable as individuals respond to learning tasks that vary according to the environment (Peterson et al., 2009). The present research has provided empirical evidence of learning style differences according to career stages and transitions in the context of production as well as sales-focused employees. To explain why learning style differences occur, a more thorough and detailed analysis of each salient work role would be necessary, including the norm and expectation of the work role, the skills and capabilities it demands, and its shared motives. An endeavor to make a theoretical connection between learning styles and salient work roles would be an important and promising next step.

Knowledge workers' experience in their first job has an enduring impact on their career development (Greenhaus \& Callanan, 2006). To make a smooth transition, individuals must acquire the knowledge and skills demanded for their next job, including occupation-specific skills (Greene \& Staff, 2012), and executive skills (Boyatzis \& Kolb, 1995), depending on the career stage entered. To effectively learn those skills and others required for work adaptation, this study suggests that individuals need to become more active learners than in the past, especially in the transition from undergraduates to nonmanagement workers, and then from nonmanagement workers to managers as well. Additionally, those who reenter work with an MBA degree may face challenges due to the gap between MBA learning contexts and management learning situations. In this regard, it may be useful for career counselors in undergraduate and business schools as well as human resources specialists in organizations to provide guidance or an orientation that includes learning style differences and changes over these transitions.

\subsection{Limitations}

This study had several limitations. The first limitation is the cross-sectional research design that examined learning style differences in cohorts from undergraduates to managers. Although the study provided useful results regarding individuals' career development, a longitudinal research design should be used to confirm how the same persons differ with their career. The second limitation is the Japanese research context used for this study. Although Japanese MBA students' learning styles in this study were similar to those of Americans, the learning styles of the other three cohorts that emphasized CE (feeling) modes seem to be a characteristic of Japanese culture (Yamazaki, 2005). In order to generalize learning style differences and change from undergraduate study through management positions, studies in other countries would be beneficial, providing insight on how students and workers develop their career towards management across countries.

\section{References}

Ashforth, B. E., \& Saks, A. M. (1995). Work-role transitions: A longitudinal examination of the Nicholson model. Journal of Occupational Psychology, 68, 157-175. http://dx.doi.org/10.1111/j.2044-8325.1995.tb00579.x

Austin, Z. (2004). Learning styles of pharmacists: Impact on career decisions, practice patterns and teaching method preferences. Pharmacy Education, 4, 13-22. https://doi.org/10.1080/1560221042000193310

Ballout, H. I. (2009). Career commitment and career success: Moderating role of self-efficacy. Career Development International, 14(7), 655-670. http://dx.doi.org/10.1108/13620430911005708

Boyatzis, R. E., \& Kolb, D. A. (1995). From learning styles to learning skills: The executive skills profile. Journal of Managerial Psychology, 10, 3-17. http://dx.doi.org/10.1108/02683949510085938

Boyatzis, R. E., \& Mainemelis, C. (2000). An empirical study of pluralism of learning and adaptive styles in an MBA program (Working paper series No. 00-1). Cleveland, OH: Department of Organizational Behavior, Weatherhead School of Management, Case Western Reserve University.

Brown, H. D., \& Burke, R. C. (1987). Accounting education: A learning styles study of professional-technical and future adaptation issues. Journal of Accounting Education, 5, 187-206. http://dx.doi.org/10.1016/0748-5751(87)90018-2

Callero, P. L. (1985). Role-identity salience. Social Psychology Quarterly, 48(3), $203-215$. http://dx.doi.org/10.2307/3033681

Cassidy, S. (2004). Learning styles: An overview of theories, models, and measures. Educational Psychology, 24, 419-444. http://dx.doi.org/10.1080/0144341042000228834

Demirbas, O. O., \& Demirkan, H. (2007). Learning styles of design students and the relationship of academic performance and gender in design education. Learning and Instruction, 17, 345-359. http://dx.doi.org/10.1016/j.learninstruc.2007.02.007

DuBrin, A. J. (2007). Fundamentals of organizational behavior, 4th ed. Mason, OH: Thomson South-Western. 
Duff, A. (2004). A note on the problem solving style questionnaire: An alternative to Kolb's Learning Style Inventory? Educational Psychology, 24, 699-709. http://dx.doi.org/10.1080/0144341042000262999

Fort, I., Jacquet, F., \& Leroy, N. (2011). Self-efficacy, goals, and job search behaviors. Career Development International, 16(5), 469-481. http://dx.doi.org/10.1108/13620431111168886

Greene, K. M., \& Staff, J. (2012). Teenage employment and career readiness. New Directions for Youth Development, 134, 23-31. http://dx.doi.org/10.1002/yd.20012

Greenhaus, J. H., \& Callanan, G. A. (2006). Encyclopedia of career development, 1. Thousand Oaks, CA: Sage. https://doi.org/10.4135/9781412952675

Grimm, V., \& Nachmias, C. (1977). The effect of cognitive style and manifest anxiety on intellectual and vocational interest in adolescents. Journal of Vocational Behavior, 10, 146-155. http://dx.doi.org/10.1016/0001-8791(77)90051-3

Hall, D. T., \& Mirvis, P. H. (1995). The new career contract: Developing the whole person at midlife and beyond. Journal of Vocational Behavior, 47, 269-289. http://dx.doi.org/10.1006/jvbe.1995.0004

Hawk, T. F., \& Shah, A. J. (2007). Using learning style instruments to enhance student learning. Decision Sciences Journal of Innovative Education, 5(1), 1-19. http://dx.doi.org/10.1111/j.1540-4609.2007.00125.x

Hill, L. (2007). Becoming the boss. Harvard Business Review (a Japanese version), 32(3), 58-71.

Holland, J. L. (1992). Making vocational choices: A theory of vocational personalities and work environments. Odessa, FL: Psychological Assessment Resources.

Holland, J. L., Gottfredson, G. D., \& Power, P. G. (1980). Some diagnostic scales for research in decision making and personality. Journal of Personality and Social Psychology, 39, 233-255. http://dx.doi.org/10.1037/h0077731

Judge, T. A., \& Kammeyer-Mueller, J. D. (2007). Personality and career success. In H. Gunz \& M. Peiperl (Eds.), Handbook of career studies (pp. 59-78). Thousand Oaks, CA: Sage. https://doi.org/10.4135/9781412976107.n4

Kaino, S., Ouchi, S., Owan, H., \& Hirano, M. (2011). Nihon koyoshisumemuha kawattaka. Japan Institute for Labor Policy and Training Report, 606, 2-5.

Kayes, D. C. (2005). Internal validity and reliability of Kolb's Learning Style Inventory Version 3 (1999). Journal of Business and Psychology, 20, 249-257. http://dx.doi.org/10.1007/s10869-005-8262-4

Kayes, D. C. (2007). Conclusion: Institutional barriers to experiential learning revisited. In M. Reynolds \& R. Vince (Eds.), The handbook of experiential learning and management education (pp. 417-431). Oxford, UK: Oxford University Press.

Kelan, E., \& Jones, R. D. (2009). Reinventing the MBA as a rite of passage for a boundaryless era. Career Development International, 14(6), 547-569. http://dx.doi.org/10.1108/13620430910997295

Kolb, D. A. (1984). Experiential learning: Experience as a source of learning and development. Englewood Cliffs, NJ: Prentice-Hall.

Kolb, D. A. (1999). Learning style inventory, version 3. Boston, MA: TRG Hay/McBer.

Kolb, A. Y., \& Kolb, D. A. (2005). Learning styles and learning spaces: Enhancing experiential learning in higher education. Academy of Management Learning and Education, 4, 193-212. http://dx.doi.org/10.5465/AMLE.2005.17268566

Levinson, D. J. (1978). The seasons of a man's life. New York, NY: Knopf.

MacArthur, J. (1991). Learning to learn in a work situation. Executive Development, 4(4), 14-16. http://dx.doi.org/10.1108/09533239110002688

McCall, M. W., Jr., Lombardo, M. M., \& Morrison, A. M. (1988). The lessons of experience: How successful executives develop on the job. New York: Free Press.

Moore, E. J. (1980). Using learning style preferences in planning programs for unemployed youth. Journal of Career Development, 6, 325-331. http://dx.doi.org/10.1177/089484538000600409

Nannichi, K., \& Ohira, K. (2014). Hitachi kokusaikahe datsu-nenkosei kaigaikara kanbujinzai kakuho [Asahi Shinbun Electric Edition]. $\quad$ Retrieved from http://www.asahi.com/articles/ASG9V4JCQG9VULFA00X.html?iref=comtop_6_01 
Ng, T. W. H., \& Feldman, D. C. (2007). The school-to-work transition: A role identity perspective. Journal of Vocational Behavior, 71, 114-134. http://dx.doi.org/10.1016/j.jvb.2007.04.004

Okubo, Y. (2006). Career design nyumon (Introduction) 1. Tokyo: Nihon Keizai Shinbunsha.

Perrone, L., \& Vickers, M. H. (2003). Life after graduation as a "very uncomfortable world": An Australian case study. Education and Training, 45(2), 69-78. http://dx.doi.org/10.1108/00400910310464044

Peterson, E. R., Stephen, G. R., \& Armstrong, S. J. (2009). Researching the psychology of cognitive style and learning style: Is there really a future? Learning and Individual Differences, 19, 518-523. http://dx.doi.org/10.1016/j.lindif.2009.06.003

Polach, J. L. (2004). Understanding the experience of college graduates during their first year of employment. Human Resource Development Quarterly, 15(1), 5-23. http://dx.doi.org/10.1002/hrdq.1084

Price, L. (2004). Individual differences in learning: Cognitive control, cognitive styles, and learning style. Educational Psychology, 24, 681-698. http://dx.doi.org/10.1080/0144341042000262971

Richardson, J. T. E. (2011). Approaches to studying, conceptions of learning and learning styles in higher education. Learning and Individual Differences, 21, 288-293. http://dx.doi.org/10.1016/j.lindif.2010.11.015

Schein, E. H. (1978). Career dynamics: Matching individual and organizational needs. Reading, MA: Addison-Wesley.

Schein, E. H. (1990). Career anchors: Discovering your real values. San Francisco: Jossey-Bass.

Seibert, S. E., Crant, J. M., \& Kraimer, M. L. (1999). Proactive personality and career success. Journal of Applied Psychology, 84(3), 416-427. http://dx.doi.org/10.1037/0021-9010.84.3.416

Stets, J. E., \& Harrod, M. M. (2004). Verification across multiply identities: The role of status. Social Psychology Quarterly, 67(2), 155-171. http://dx.doi.org/10.1177/019027250406700203

Sturges, J., Simpson, R., \& Altman, Y. (2003). Capitalising on learning: An exploration of the MBA as a vehicle for developing career competencies. International Journal of Training and Development, 7(1), 53-66. http://dx.doi.org/10.1111/1468-2419.00170

Sullivan, S. E., \& Crocitto, M. (2007). The developmental theories: A critical examination of their continuing impact on careers research. In H. Guns \& M. Peiperl (Eds.), Handbook of career studies (pp. 283-309). Thousand Oaks, CA: Sage. https://doi.org/10.4135/9781412976107.n15

Super, D. (1957). The psychology of careers. New York: Harper \& Row.

Super, D. E., \& Nevill, D. D. (1986). The salience inventory. Palo Alto, CA: Consulting Psychological Press.

Thoits, P. A. (1992). Identity structures and psychological well-being: Gender and marital status comparisons. Social Psychology Quarterly, 55(3), 236-256. http://dx.doi.org/10.2307/2786794

Trice, H. M., \& Morand, D. A. (1989). Rites of passage in work careers. In M. B. Arthur, D. T. Hall, \& B. S. Lawrence (Eds.), Handbook of career theory (pp. 397-416). Cambridge, UK: Cambridge University Press. https://doi.org/10.1017/CBO9780511625459.022

Trompenaars, F., \& Hampden-Turner, C. (2004). Managing people across cultures. New York: Wiley.

Veres, J. G., Sims, R. R., \& Locklear, T. S. (1991). Improving the reliability of Kolb's revised LSI. Educational and Psychological Measurement, 51, 143-150. http://dx.doi.org/10.1177/0013164491511013

Volodina, A., Nagy, G., \& Koller, O. (2015). Success in the first phase of the vocational career: The role of cognitive and scholastic abilities, personality factors, and vocational interests. Journal of Vocational Behavior, 91, 11-22. http://dx.doi.org/10.1016/j.jvb.2015.08.009

Yamazaki, Y. (2005). Learning styles and typologies of cultural differences: A theoretical and empirical comparison. International Journal of Intercultural Relations, 29(5), 521-548. http://dx.doi.org/10.1016/j.ijintrel.2005.07.006

Yamazaki, Y., \& Kayes, D. C. (2007). Expatriate learning: Exploring how Japanese managers adapt in the United States. International Journal of Human Resource Management, 18, 1373-1395. http://dx.doi.org/10.1080/09585190701502521

Zacher, H. (2014). Individual difference predictors of change in career adaptability over time. Journal of Vocational Behavior, 84, 188-198. http://dx.doi.org/10.1016/j.jvb.2014.01.001 